Vol. 2 | No. 4 | $2021 \mid$ Hal. 305-310

\title{
PEDAMPINGAN PEMBELAJARAN BAHASA INGGRIS PADA MASA COVID-19 UNTUK PELAJAR SEKOLAH DASAR
}

\author{
Efendi S Wirateruna*, Adila Farchamnia Olfiyanto, Chelsea Rahmadhani, Intan \\ Rifaini \\ Fakultas Teknik, Universitas Islam Malang \\ *Korespondensi email: efendi.s.wirateruna@unisma.ac.id
}

\begin{abstract}
ABSTRAK
Wabah Covid-19 telah memberi dampak semua sektor termasuk sektor pendidikan, sehingga diperlukan pendampingan pendidikan semasa pandemi. Tujuan yang ingin dicapai dalam melaksanakan kegiatan pengajaran dan pembelajaran Bahasa Inggris ini adalah untuk membantu meningkatkan kemampuan dan pengetahuan siswa dan siswi mengenai Bahasa Inggris di Sekolah Dasar Negeri 2 Labuapi di Desa Labuapi, kec. Labuapi, kab. Lombok barat, nusa tenggara barat. Salah satu upaya yang dilakukan untuk meningkatkan pembelajaran Bahasa Inggris ini adalah dengan pengajaran materi, serta praktik pelafalan Bahasa Inggris dengan menggunakan metode pembelajaran belajar sambil bermain. Pelaksanaan kegiatan ini terdiri dari beberapa tahapan; tahap pertama yaitu survey lokasi Sekolah Dasar Negeri 2 Labuapi; tahap kedua yaitu berkoordinasi dengan kepala sekolah dan kepala desa; tahap ketiga persiapan pelaksanaan; tahap keempat adalah pelaksanaan kegiatan pengajaran dan pembelajaran Bahasa Inggris. Indikator keberhasilan kegiatan pedampingan pembelajaran Bahasa inggris adalah pembuatan modul vocabulary dan Rancangan Pelaksanaan Pembelajaran (RPP) Bahasa Inggris. Dengan adanya pencetakan modul, keberlanjutan program pembelajaran Bahasa inggris yang efektif dan tepat untuk siswa SD dapat tercapai.
\end{abstract}

Kata Kunci: Modul Bahasa Inggris; Rancangan Pelaksanaan Pembelajaran

\section{PENDAHULUAN}

Wabah virus korona (Covid-19) yang telah terjadi dari awal maret 2020 hingga saat ini banyak memberikan dampak yang sangat besar terhadap sektor-sektor yang ada di Indonesia mulai dari sektor ekonomi, kesehatan, sosial dan juga sektor pendidikan. (WHO, 2020) (KEMENKES, 2021). Sektor pendidikan mengalami perubahan secara signifikan menuju sistem yang lebih modern dan relevan dengan keadaan saat ini (Suhartoyo, et al., 2020). Sektor pendidikan adalah sektor yang sangat vital dan membutuhkan dukungan dari berbagai pihak. Tinggi rendahnya kualitas pendidikan dapat mempengaruhi kemajuan suatu negara tersebut (Puspitasari \& Hidayatullah, 2020) (Setiawan, et al., 2021) (Widiansyah, 2017). Selain pendidikan formal di sekolah, proses pendidikan nonformal dan informal dapat dilaksanakan untuk menunjang pengetahuan dan keterampilannya (Dinasari, Saroh, \& Sumartono., 2018) (Ernawati \& Mulyono, 2017).

Desa Labuapi adalah salah satu tempat terdampaknya akibat Covid 19 baik dalam aspek ekonomi, sosial dan pendidikan. Dampak dari pandemi covid-19 dalam sektor pendidikan ini banyak sekolah yang menggunakan sistem pendidikan jarak jauh atau belajar dari rumah, namun terdapat beberapa permasalahan dan kesulitan yang banyak dihadapi 
siswa dan siswi dalam melaksakan kegiatan pembelajaran jarak jauh. Beberapa kendala yang dialami dalam pengajaran jarak jauh yaitu kendala dalam infrastruktur jaringan internet, peralatan komputer, laptop, maupun IT lainnya, dan juga menurunnya tingkat pendapatan ekonomi orang tua siswa dan siswi. Selain itu siswa dan siswi juga merasakan kurangnya efisiensi belajar menggunakan sistem pembelajaran jarak jauh ini.

Pengabdian masyarakat merupakan salah satu komponen wajib aktivitas akademik yang merupakan bagian dari Tri Dharma Perguruan Tinggi selain pengajaran dan penelitian (Dzurrahmi, et al., 2021). Dengan hal itu mahasiswa dari KSM-Tematik dari kelompok 120 Universitas islam malang melaksanakan kegiatan pengajaran dan pembelajaran kepada siswa - siswi untuk menyalurkan ilmu demi meningkatkan pengetahuan dan kemampuan siswa - siswi terutama dalam peningkatan kemampuan Bahasa Inggris.

Berdasarkan uraian yang telah dipaparkan, permasalahan yang terjadi adalah minimnya fasilitas yang dapat digunakan untuk pengajaran dan pembelajaran siswa-siswi serta kurang kondusifnya tempat pengajaran dan pembelajaran yang dilaksanakan. Selain itu kurangnya ketangkasan berfikir serta kecakapan siswa dalam menjalani pembelajaran juga menjadi salah satu masalah yang dihadapi.

\section{METODE}

Dalam metode pelaksanaan ini mahasiswa berdiskusi dan bekerja sama dengan guru dan kepala sekolah mengenai apa saja yang perlu dikembangkan dengan usulan dari kelompok KSM-Tematik untuk melaksanakan program kerja pokok yang sudah direncanakan yaitu Pengajaran Bahasa Inggris untuk siswa - siswi Kelas III, IV, V SDN 2 LABUAPI. Metode pelaksanaan kegiatan yang dilakukan meliputi:

(1) Tahap Pertama; melakukan survey di Sekolah Dasar Negeri 2 Labuapi dengan tujuan mendapatkan informasi lokasi terkait sistem dan konsisi pembelajaran.

(2) Tahap Kedua; meminta izin kepada kepala sekolah dan guru untuk melaksanakan program kerja.

(3) Tahap Ketiga; Persiapan bahan pembelajaran yang diperlukan untuk pelaksanaan pengajaran Bahasa Inggris.

(4) Tahap Keempat Pelaksanaan pengajaran dan pembelajaran Bahasa Inggris kepada siswa dan siswi Sekolah Dasar Negeri 2 Labuapi

kegiatan ini dilaksanakan disalah satu tempat yang terletak di Desa Labuapi. Kegiatan berlangsung mulai bulan agustus hingga september.

\section{HASIL DAN PEMBAHASAN}

Pada kegiatan KSM-Tematik yang merupakan program pengabdian ini terdapat beberapa tahapan dalam pelaksanaan program kerja, tahap pertama adalah tahap survey dan sosialisasi, kegiatan ini bertujuan untuk memaparkan gambaran secara menyeluruh mengenai program kegiatan yang akan dilaksanakan oleh tim pengabdi. Guru serta siswa dan siswi menyambut baik pelaksanaan kegiatan ini dengan harapan siswa - siswi Sekolah Dasar Negeri 2 Labuapi mendapatkan ilmu baru dan dapat meningkatkan kemampuan dalam berBahasa Inggris. Tahapan selanjutnya yaitu melaksanakan persiapan bahan ajar untuk pembelajaran Bahasa Inggris dan tahapan yang terakhir adalah pelaksanaan pengajaran dan pembelajaran Bahasa Inggris, pelaksanaan kegiatan pengajaran dan pembelajaran ini menggunakan sistem pembelajaran belajar sambil bermain dengan penyampaian materi serta praktik pelafalan Bahasa Inggris.

Indikator keberhasilan yang dapat diukur dalam kegiatan kali ini adalah siswa siswa - siswi mampu melafalkan vocabulary yang diberikan sesuai dengan pronounciation yang baik dan benar. Dalam prosesi belajar mengajar sangat perlu adanya fasilitas penunjang 
untuk mengembangkan ilmu pengetahuan, nilai, sikap dan keterampilan peserta didik serta memudahkan pengajar dalam menyampaikan materi pembelajaran, Oleh karena itu, bukti perwujudan fasilitas tersebut kami tuangkan kepada hasil pembuatan 4 modul khusus vocab bahasa inggris dan pencetakan modul paket B sebanyak 210 modul

Tabel 1. Presentase

\begin{tabular}{lcc}
\multicolumn{1}{c}{ Lokasi } & $\begin{array}{c}\text { Jumlah siswa yang } \\
\text { diajar }\end{array}$ & $\begin{array}{c}\text { Jumlah siswa yang } \\
\text { memiliki potensi }\end{array}$ \\
\hline Desa Labuapi, Kec. Labuapi, Lombok Barat, NTB & 80 & 45 \\
Desa Ubung, Kec.Jonggat Lombok Tengah & 30 & 18 \\
\hline
\end{tabular}

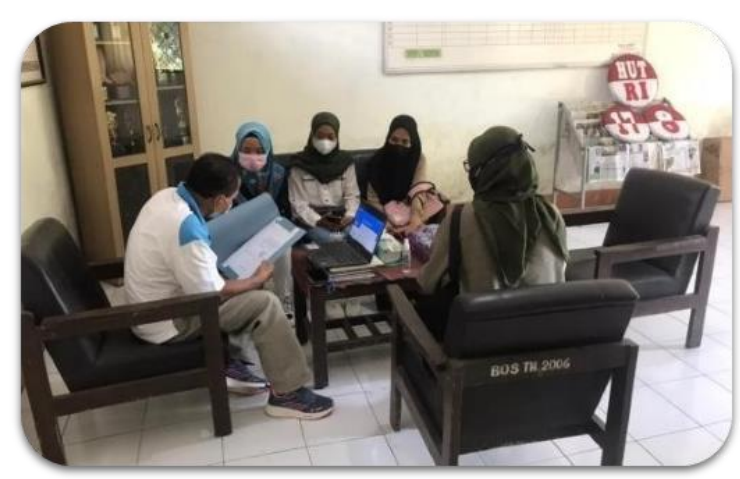

Gambar 1. Sosialisasi dengan kepala sekolah

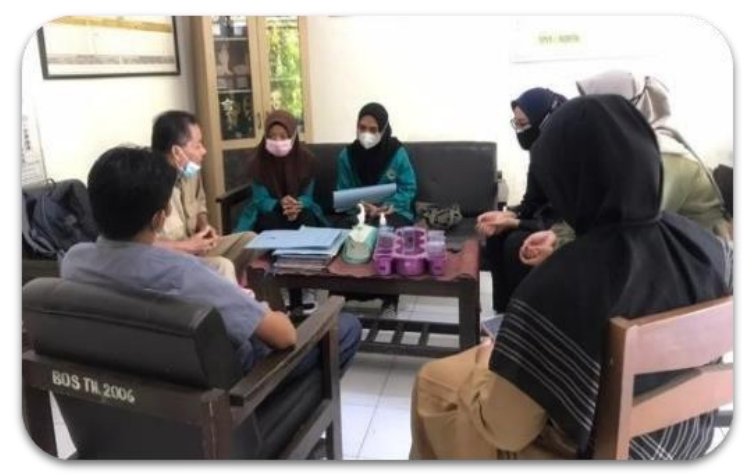

Gambar 2. Sosialisasi dengan guru-guru

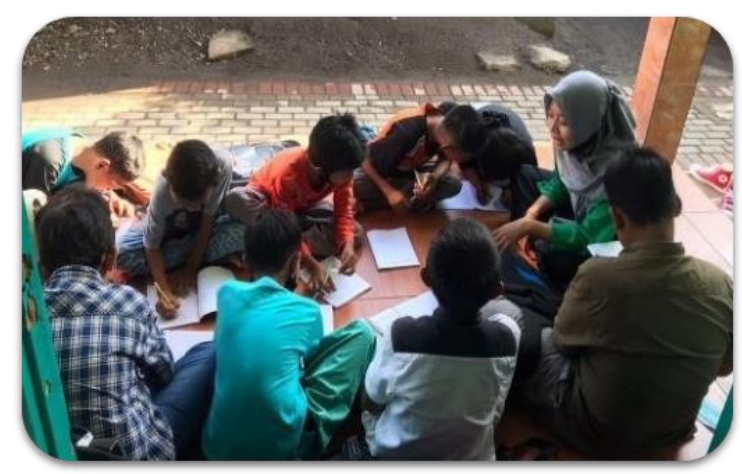

Gambar 3. Pengajaran Bahasa Inggris minggu pertama 


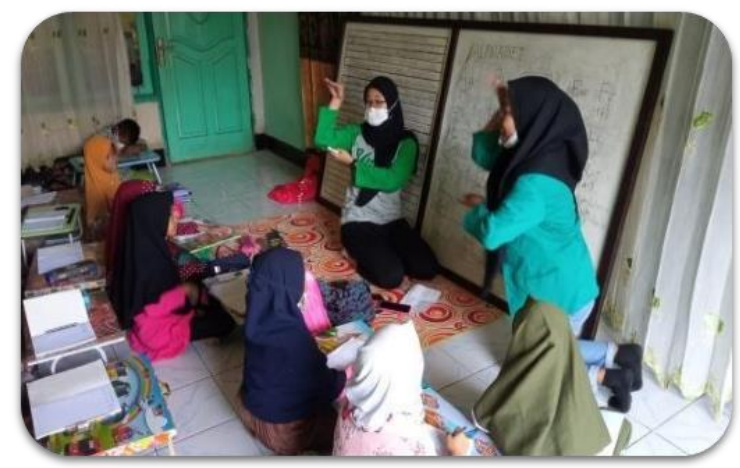

Gambar 4. Pengajaran Bahasa Inggris minggu kedua

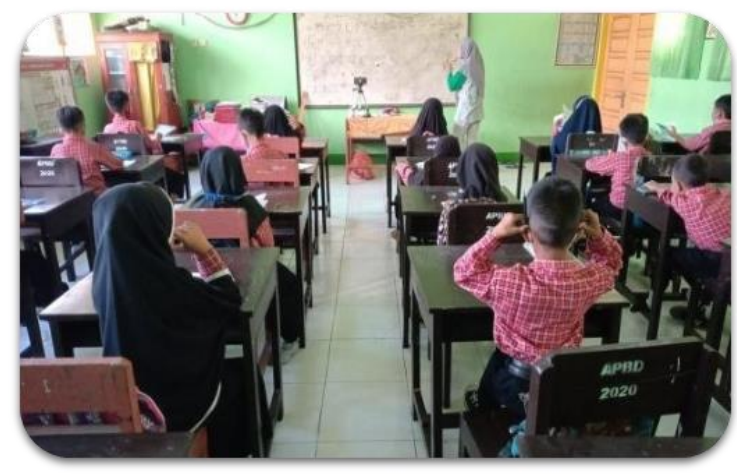

Gambar 5. Pengajaran Bahasa Inggris minggu ketiga

Sumber daya manusia atau guru di SD 2 Labuapi yang mengajar pelajaran Bahasa inggris tidak ada sehingga untuk mengisi pelajaran Bahasa inggris para guru tidak memiliki persiapan yang matang baik dalam hal materi atau modul serta teknik dalam penyampaian materi Bahasa inggris yang menarik. Untuk memulai kegiatan, pada gambar 1 dan 2 tim KSM koordinasi dengan kepala sekolah yang dihadiri oleh para guru pengampu pelajaran Bahasa inggris sementara untuk menyamakan persepsi terkait mata pelajaran Bahasa inggris.

Kegiatan pembelajaran Bahasa inggris dilakukan secara terbuka, gambar 4, atau dilaksanakan di luar jam sekolah maupun dilaksanakan di dalam kelas dengan tetap mematuhi protokol Kesehatan yang ketat pada gambar 6. Pembelajaran Bahasa inggris membutuhkan teknik yang unit dan menarik untuk anak SD sehingga semangat untuk belajar Bahasa asing tinggi. Salah satu teknik yang paling penting dalam pembelajaran Bahasa inggris adalah tingkat percaya diri siswa dalam berbicara Bahasa inggris sangat diperlukan.

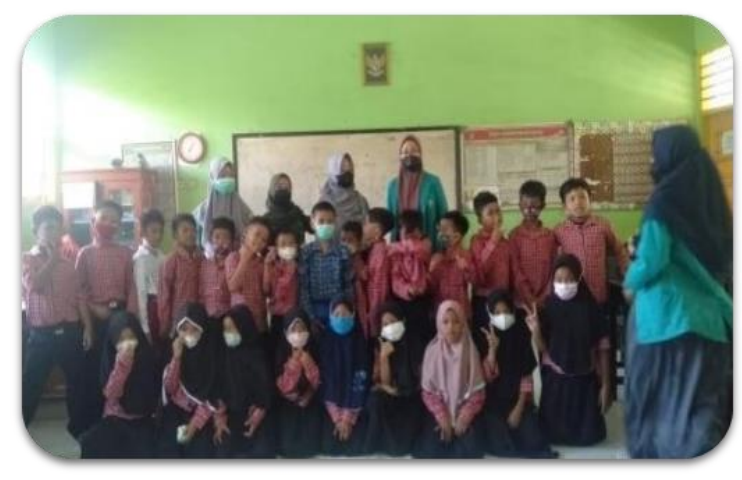

Gambar 6. Perpisahan dengan siswa - siswi 


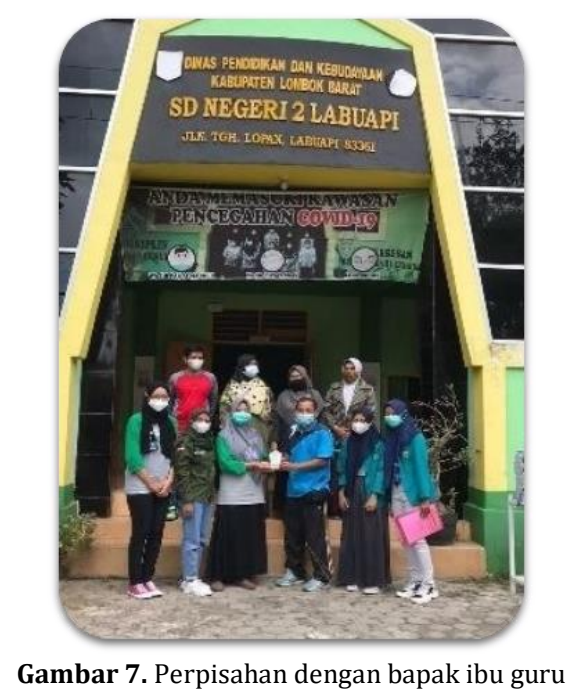

Kegiatan diakhiri dengan penyerahan modul Bahasa inggris tentang kumpulan kosa kata Bahasa inggris daily activities serta draft rancangan pembelajaran Bahasa inggris kepada kepala sekolah SDN 2 Labuapi pada gambar 7. Selain itu, perpisahan juga dilaksanakan di akhir kelas dengan para siswa, gambar 6. Respon positif datang langsung dari pihak kepala sekolah dan guru SDN 2 Labuapi tentang manfaat produk modul Bahasa inggris dan draft Rencana Pelaksanaan Pembelajaran (RPP) Bahasa inggris yang digunakan langsung oleh guru pengajar Bahasa inggris dalam kelas.

\section{KESIMPULAN}

Program kerja yang dilakukan mahasiswa KSM-Tematik kelompok 120 di Sekolah Dasar Negeri 2 Labuapi di Desa Labuapi, Kec. Labuapi, Kab. Lombok Barat, Nusa Tenggara Barat, telah menunjukan hasil yang baik. Dari kegiatan-kegiatan tersebut hasil yang didapatkan yakni siswa dan siswi dapat menerima ilmu baru serta dapat mengingkatkan kemampuan dalam berBahasa Inggris dengan baik.

Dalam prosesi belajar mengajar sangat perlu adanya fasilitas penunjang untuk mengembangkan ilmu pengetahuan, nilai, sikap dan keterampilan peserta didik serta memudahkan pengajar dalam menyampaikan materi pembelajaran, Oleh karena itu, bukti perwujudan fasilitas tersebut kami tuangkan kepada hasil pembuatan 4 modul khusus vocab bahasa inggris dan draft Rencana Pelaksanaan Pembelajaran (RPP) Bahasa inggris. Dengan adanya pencetakan modul, keberlanjutan program pembelajaran Bahasa inggris yang efektif dan tepat untuk siswa SD dapat tercapai.

\section{UCAPAN TERIMA KASIH}

Ucapan terimakasih disampaikan kepada Kepala Sekolah SDN 2 Labuapi dan bapak ibu guru pengajar yang telah menerima dan membantu mahasiswa peserta KSM-Tematik dalam menjalankan progam kerja. Ucapan terimakasih juga disampaikan kepada Ketua LPPM Universitas Islam Malang yang telah memberikan kesempatan dan terlaksananya kegiatan KSM-Tematik.

\section{DAFTAR RUJUKAN}

Dinasari, I., Saroh, S., \& Sumartono. (2018). Pemanfaatan Potensi Lokal Lembaga Pendidikan Madrasah Sebagai Pembelajaran Usaha Produktif. Jurnal Inovasi Hasil Pengabdian Masyarakat (IIPEMAS), $1(1)$, 39-53. doi:https://doi.org/10.33474/jipemas.v1i1.1478 
Dzurrahmi, B. D., Asniwati, A. A., Sarmadiyanti, B. N., Lestari, H. F., Ayunah, S. A., Ridwan, M. H., \& Zubair, M. (2021). Pendampingan Pendidikan Non-Formal di Desa Wisata Hijau Bilebante dalam Kelompok Belajar "Bale Cerdas". Jurnal Pengabdian Magister Pendidikan IPA, 4(1), 2-7. doi:https://doi.org/10.29303/jpmpi.v4i1.606

Ernawati, \& Mulyono, S. E. (2017). Manajemen Pembelajaran Program Paket C Di Pkbm Bangkit Kota Semarang. Journal of Nonformal Education, 3(1), 60-71. doi:https://doi.org/10.15294/jne.v3i1.8915

KEMENKES. (2021, Agustus 3). Covid-19. Diambil kembali dari Infeksi Emerging: https://infeksiemerging.kemkes.go.id/

Puspitasari, N. A., \& Hidayatullah, S. (2020). Peningkatan wawasan penerapan model pembelajaran berorientasi HOTS (Higher Order Thinking Skill) bagi guru MTs dan MA. Jurnal Inovasi Hasil Pengabdian Masyarakat (JIPEMAS), 3(2), 128-135. doi:https://doi.org/10.33474/jipemas.v3i2.6131

Setiawan, E., Jannah, L., Rahmawati, Mukaromah, S., Pujiyanti, D., \& Zelitha, A. (2021). Poster Edukasi dan Pendampingan Pembelajaran pada Era New Normal di Taman Pendidikan Al-Qur'an. Jurnal Pembelajaran Pemberdayaan Masyarakat, 2(2), 111117.

Suhartoyo, E., Wailissa, S. A., Jalarwati, S., Samsia, S., Wati, S., Qomariah, N., \& Dayanti, E. (2020). Pembelajaran Kontekstual Dalam Mewujudkan Merdeka Belajar. Jurnal Pembelajaran Pemberdayaan Masyarakat (JP2M), 1(3), 161-164. doi:https://doi.org/10.33474/jp2m.v1i3.6588

WHO. (2020). Transmisi SARS-CoV-2: implikasi terhadap kewaspadaan pencegahan infeksi. 1-10.

Widiansyah, A. (2017). Peran Ekonomi dalam Pendidikan dan Pendidikan dalam Pembangunan Ekonomi. Jurnal Cakrawala, 17(2), 207-215. doi:https://doi.org/10.31294/jc.v17i2.2612 